\title{
Inflammation-associated gene expression is altered between normal human ovarian surface epithelial cells and cell lines derived from ovarian adenocarcinomas
}

\author{
O Gubbay ${ }^{*, 1}$, W Guo', MT Rae', D Niven', SP Langdon² and SG Hillier' \\ 'Centre for Reproductive Biology, The Chancellor's Building, University of Edinburgh, 49 Little France Crescent, Old Dalkeith Road, Edinburgh EHI 6 4SB, \\ UK; ${ }^{2}$ Cancer Research UK, Edinburgh Oncology Unit, Western General Hospital, Edinburgh EH4 2XU, UK
}

\begin{abstract}
Ovulation is believed to contribute to the development of ovarian cancers that derive from the ovarian surface epithelium (OSE). The process of ovulation is synonymous with inflammation and inflammatory cytokines such as interleukin- $\mid \alpha(\mathrm{IL}-\mid \alpha)$ have recently been shown to induce both inflammatory and anti-inflammatory responses in human OSE (HOSE) cells. In this study we directly compared levels of IL- | $\alpha$-induced gene expression by analysing the levels of I | $\beta$-hydroxysteroid dehydrogenase (I | $\beta$ HSD) types | ( I I $\beta$ HSD-I) and 2 ( I | $\beta$ HSD-2), cyclooxygenase-2 (COX-2), IL-I receptor (IL-IR) and glucocorticoid receptor $\alpha$ (GR $\alpha$ ) mRNA between normal HOSE cells and cell lines derived from poorly differentiated (SKOV-3, BG-I, PEO-4) and well-differentiated (PEO-14) ovarian adenocarcinoma. In HOSE cell cultures, and to a lesser extent PEO- 14 cells, the basal mRNA levels of COX-2 and I I $\beta$ HSD-I were relatively high and further shown to be induced in response to IL-I $\alpha$ (for HOSE cells; $>20$-fold, $P<0.05$ and PEO-I 4 cells; > 3fold, $P<0.05$ ). However, whereas HOSE cells expressed a low level of I I $\beta$ HSD-2 mRNA that was only mildly responsive to $\mathrm{IL}-\mid \alpha(\mid$.3-fold, $P<0.00 \mathrm{I})$, all cell lines exhibited a higher basal level of $\mid \mathrm{I} \beta \mathrm{HSD}-2 \mathrm{mRNA}$ that was in some cases further stimulated in PEO-4 cells (five-fold; $P<0.05$ ) or suppressed in SKOV-3 cells (two-fold; $P<0.0 \mathrm{I}$ ) in response to IL-I $\alpha$. All cells tested expressed IL-IR and, with the exception of BG-I, GR $\alpha$. These results indicate that cell lines derived from ovarian cancers have lost the ability to respond normally to inflammatory cytokines such as $\mathrm{IL}-\mid \alpha$. The finding that normal OSE cells, in contrast to cell lines derived from patients with ovarian adenocarcinoma, abundantly express I I $\beta$ HSD- I mRNA but are essentially devoid of I I $\beta$ HSD-2 mRNA supports the concept that the pattern of II $\beta \mathrm{HSD}$ isoform gene expression is a defining feature of neoplastic cellular transformation, which might have particular relevance to the ovary.
\end{abstract}

British Journal of Cancer (2005) 92, 1927-1933. doi:I0.1038/sj.bjc.6602568 www.bjcancer.com

Published online 3 May 2005

(c) 2005 Cancer Research UK

Keywords: ovarian cancer; ovarian surface epithelium; I / $\beta \mathrm{HSD}-$ I/2; inflammation

The surface of the ovary is covered by a continuous layer of cuboidal epithelial cells known as the ovarian surface epithelium (OSE). Although human OSE (HOSE) cells have been collected, cultured and studied in vitro, their natural function beyond forming a physical barrier between ovary and other peritoneal surfaces is unclear (Auersperg et al, 2001). The OSE cell layer, however, would appear to be important for ovulation since ovulation does not proceed in its absence (Colgin and Murdoch, 1997). Repeated episodes of ovulation-associated injury and repair are presumed to underlie the high frequency of ovarian carcinoma arising from the OSE (Fathalla, 1971; Salazar et al, 1996), which account for $90 \%$ of all ovarian cancers (Ozols, 1991). Since ovulation is a natural inflammatory process (Espey, 1980a,b), factors related to inflammation of the OSE have been associated with increased risk of ovarian cancer (Ness and Cottreau, 1999;

*Correspondence: Dr O Gubbay; E-mail: ogubby@staffmail.ed.ac.uk Received I November 2004; revised 24 January 2005; accepted 17 March 2005; published online 3 May 2005
Ness et al, 2000). It is therefore critically important to understand how inflammatory cell damage is normally resolved in the OSE.

The inflammatory response at ovulation induces extensive tissue remodelling (Murdoch et al, 1999; Bukulmez and Arici, 2000) and accompanying cell death that is observed within OSE cells (Murdoch et al, 1999). Mutations responsible for generating cancerous cells are believed to arise from DNA replication/repair errors during subsequent rounds of OSE cell proliferation. The rate of mutation is further believed to increase in the presence of toxic oxidants that are released during such an inflammatory response (Ness and Cottreau, 1999).

In patients with ovarian cancer, increased levels of IL-1 and IL-1R are present in serum (Zeisler et al, 1998; Kondera-Anasz et al, 2003). These levels, however, are suggested to arise as a consequence of ovarian cancer, rather than playing any causal role (Punnonen et al, 1991; Kutteh and Kutteh, 1992). This is further exemplified by the positive effect of IL- $1 \alpha$ treatment in patients with ovarian cancer (Buescher et al, 1993; Lee et al, 1993; Vadhan-Raj et al, 1994; Verschraegen et al, 1996). A closer look at the IL-1 $\alpha$ gene in cancer patients showed no association with polymorphisms (Hefler et al, 2002). However, polymorphism of the interleukin receptor 
antagonist (IL-1RA) gene was shown to be associated with ovarian cancer (Sehouli et al, 2003a,b, 2002). In patients with ovarian cancer, IL-1RA is present at increased levels (Burger et al, 1994; Fujiwaki et al, 1997; Kondera-Anasz et al, 2003). More detailed studies on the role of IL- $1 \alpha$ in ovarian cancer have produced conflicting results. Thus, while IL-1 is reported to increase ovarian cancer cell growth in an autocrine fashion (Marth et al, 1996; Huleihel et al, 1997; Kawakami et al, 1997), IL-1 is documented to enhance ovarian cancer cell death and inhibit cellular repair mechanisms (Benchekroun et al, 1995; Wang et al, 1996).

Interleukin-1, the prototypical inflammatory cytokine known to be produced in association with ovulation is documented to stimulate inflammatory changes in primary HOSE cell cultures, measured as increased gene expression of cyclooxygenase-2 (COX2) (Rae et al, 2004) and matrix metalloproteinases (Niven et al, 2004). IL-1 $\alpha$ also simultaneously induces increased expression and activity of $11 \beta$-hydroxysteroid dehydrogenase type 1 (11 $\beta \mathrm{HSD}-1)$ in HOSE cells (Yong et al, 2002). 11ßHSD-1 is a steroid dehydrogenase/reductase enzyme that reversibly promotes increased formation of cortisol from substrate cortisone (Tannin et al, 1991; Stewart and Mason, 1995). The local increase of cortisol is believed to play a role in providing an anti-inflammatory environment to counteract inflammation caused at ovulation (Andersen and Hornnes, 1994; Escher et al, 1997; Hillier and Tetsuka, 1998; Yong et al, 2002; Rae et al, 2004). In addition to $11 \beta \mathrm{HSD}-1$, an additional $11 \beta \mathrm{HSD}$ isoform, $11 \beta \mathrm{HSD}-2$, converts cortisol to cortisone; reviewed in Michael et al (2003). Although inflammatory stimulation appears not to alter expression of $11 \beta$ HSD-2 in HOSE cells (Rae et al, 2004), an increased level of $11 \beta \mathrm{HSD}-2$ is present within tumors that originate from breast, colon, adipose, adrenal and pituatory tissue (Rabbitt et al, 2003).

Here we directly compared the levels of gene expression of COX-2, $11 \beta$ HSD -1 and -2 in response to treatment with IL- $1 \alpha$ in normal HOSE cells and a series of cell lines derived from the ovaries of patients with ovarian adenocarcinoma (Langdon et al, 1988).

\section{MATERIALS AND METHODS}

\section{Isolation of HOSE cells}

HOSE cells were obtained with informed consent after local ethical committee approval from the ovaries of premenopausal women undergoing elective surgery for nonmalignant gynaecological conditions. Cells were collected at laparotomy by gentle scraping of the ovarian surface with a sterile wooden spatula, which was then rinsed into sterile, warmed HOSE1 culture media (see below). Cells were collected as near to the beginning of surgical procedure as practicable to avoid any contamination with blood cells. Collections were then examined by phase-contrast microscopy to ensure that sufficient flakes of OSE had been obtained and cultured in donor calf serum-precoated flasks $\left(75 \mathrm{~cm}^{2}\right.$, Corning Inc., Glass Works, Corning NY, USA).

\section{Culture of HOSE cells}

Culture media (HOSE 1) consisted of Medium199:MCDB105 $\left(1: 1 \mathrm{vv}^{-1}\right)$ supplemented with foetal calf serum $\left(15 \% \mathrm{vv}^{-1}\right)$, streptomycin $\left(50 \mu \mathrm{g} \mathrm{ml}^{-1}\right)$, penicillin $\left(50 \mathrm{IU} \mathrm{ml}^{-1}\right)$ and L-glutamine $\left(1 \mathrm{mmoll}^{-1}\right)(8)$. Cells were incubated at $37^{\circ} \mathrm{C}$ in a humidified incubator under an atmosphere of $95 \%$ air, $5 \% \mathrm{CO}_{2}$ for up to 28 days, with media renewed every 7 days. Confluent cell monolayers were routinely obtained in 21 days using this system. Monolayers were routinely examined by phase-contrast microscopy for contaminating cells such as fibroblasts, and confirmation of cell purity was confirmed in selected cases with immunocytochemical staining for cytokeratin 7, 8, 18 and 19 (Czernobilsky, 1985; van Niekerk et al, 1991) using a commercially available monoclonal anti-human cytokeratin antibody (Dako), which revealed that monolayers were pure epithelial cells using this culture system (data not shown). Confluent HOSE monolayers were treated with trypsin-EDTA in Hanks balanced salt solution $\left(0.05 \% \mathrm{wv}^{-1}\right.$ trypsin, $0.5 \mathrm{~mm}$ EDTA, Invitrogen) at $37^{\circ} \mathrm{C}$ for $5 \mathrm{~min}$. Cells were then collected by centrifugation at $800 \mathrm{~g}$ for $5 \mathrm{~min}$. This pellet was washed in fresh HOSE 1 media, and then resuspended in fresh media. Cell number and viability were determined by trypan blue (Sigma) exclusion counting in a haemocytometer; viability ranged from 75 to $95 \%$. HOSE cells were seeded in six-well plates $\left(50000\right.$ well $\left.^{-1}\right)$ and incubated with HOSE 1 medium for $48 \mathrm{~h}$. For treatments, HOSE cells were incubated for a further $24 \mathrm{~h}$ in Dulbecco's modified Eagle's medium nutrient F-12, containing $100 \mathrm{U} \mathrm{ml}^{-1}$ penicillin, $100 \mu \mathrm{g} \mathrm{ml}^{-1}$ streptomycin (as used for cell lines) and subsequently treated with $0.25,0.5$ or $1 \mathrm{ng} \mathrm{ml}^{-1} \mathrm{IL}-1 \alpha$ (R\&D Systems Europe Ltd, Abingdon, Oxon, UK) for a further $48 \mathrm{~h}$. All tissue culture reagents were obtained from Gibco BRL (Life technologies Ltd, Renfrewshire, UK) and Sigma Chemical Co. (Poole, Dorset, UK).

\section{Cell lines}

The following cell lines SKOV-3, BG-1, PEO-4 and PEO-14 were kindly provided by P Pujol, INSERM, Montpellier, France. Cells were routinely grown in complete medium (Dulbecco's modified Eagle's medium nutrient F-12, containing $100 \mathrm{U} \mathrm{ml}^{-1}$ penicillin, $100 \mu \mathrm{g} \mathrm{ml}^{-1}$ streptomycin and $10 \%$ foetal calf serum). The cell lines were seeded in six-well plates $\left(50000\right.$ cells well $\left.^{-1}\right)$ and incubated with serum-free medium for $24 \mathrm{~h}$. The cells were subsequently treated with $0.25,0.5$ or $1 \mathrm{ng} \mathrm{ml}^{-1} \mathrm{IL}-1 \alpha$ (R\&D Systems Europe Ltd, Abingdon, Oxon, UK) for a further $48 \mathrm{~h}$.

\section{RNA extraction and quality analysis}

RNA was extracted from HOSE cells using RNeasy minispin columns (Qiagen) as per manufacturer's protocol. In total, $1 \mu \mathrm{l}$ aliquots of purified RNA were removed for quantification and quality assessment. RNA was quantified and quality assessed using the Agilent 2100 Bioanalyser system for total RNA in combination with RNA6000nano chips (Agilent Technologies, Cheshire, UK). Only RNA that displayed intact $18 \mathrm{~S}$ and $28 \mathrm{~S}$ peaks was reverse transcribed to cDNA for PCR analysis. This quality control step was included for each experimental run to avoid generation of false negative results due to RNA degradation prior to and during extraction steps, and also as a quantification method to ensure equal amounts of RNA were transcribed in each RT- reaction.

\section{Real-time PCR analysis}

Total RNA ( $1 \mu \mathrm{g})$ was treated with DNAase (Invitrogen) as per the manufacturer's protocol. In total, $200 \mathrm{ng}$ treated RNA was reverse transcribed (random hexamer kit; Applied Biosystems), and $2 \mu \mathrm{l}$ of the RT-mix was analysed. cDNA was analysed in a $25 \mu \mathrm{l}$ final volume assay system containing $300 \mathrm{nmoll}^{-1}$ primers and $200 \mathrm{nmoll}^{-1}$ TaqMan hybridisation probe (Biosource UK Ltd). Primers and probes were designed using Primer-Express software (Perkin-Elmer), where possible spanning intron regions to avoid any poterntial of genomic DNA amplification. For human $11 \beta \mathrm{HSD}-1$, the following was used: forward primer (AGG ATC TTC CTG CAT GGA TTT C), reverse primer (AGC TCT GCG CCA AGA AGA AGT) and probe (TGA CAG CTC ACT CTG GAC CAC TCT TCT GA). For human $11 \beta \mathrm{HSD}-2$, the following was used: forward primer (GGC CAA GGT TTC CCA GTG A), reverse primer (GTT GTG CCA GGA GGG TGT TT) and probe (CTC TGC GCC TCT CCA CTG TTT CAT GA). For human COX-2, the following was used: forward primer (CCT TCC TCC TGT GCC TGA TG), reverse primer (ACA ATC TCA TTT GAA TCA GGA AGC T) and probe (TGC CCG ACT CCC TTG GGT GTC A). For human IL-1R (type 1), the following was used: forward primer (TGT CAC CGG 
CCA GTT GAG T), reverse primer (GCA CTG GGT CAT CTT CAT CAATT) and probe (ACA TTG CTT ACT GGA AGT GGA ATG GGT CAG). Target mRNA was quantified in relation to $18 \mathrm{~S}$ ribosomal RNA abundance in each sample, with suitable positive control RNA (human liver total RNA from Ambion and in house prepared human placental mRNA). Negative controls included RT-negative samples (RNA template with no reverse transcriptase enzyme), $\mathrm{RT}-\mathrm{H}_{2} \mathrm{O}$ (water in place of RNA template) samples generated at the time of reverse transcription of samples and a Taqman reaction negative control where cDNA was replaced with water. Primer and probe sets for COX-2 were the kind gifts of $\mathrm{Dr} \mathrm{H}$ Jabbour (HRSU, Medical Research Council, Edinburgh, UK). Data are presented relative to $18 \mathrm{~S}$ as mean \pm s.e.m. and statistics performed using the superANNOVA package from Abacus Concepts, Inc.

\section{Analysis of RT - PCR by agarose gel electrophoresis}

Reverse transcription reactions were conducted in a volume of $50 \mu \mathrm{l}$ consisting of $2 \mu \mathrm{g}$ of total RNA, $10 \mathrm{ng}$ oligo-dT (Gibco Invitrogen Corporation), $0.01 \mathrm{~m} \mathrm{DTT}, 1 \mathrm{~mm}$ dNTPs and Superscript reverse transcriptase (Gibco Invitrogen Corporation). PCR was performed in $25 \mu \mathrm{l}$ reactions, containing $2 \mu \mathrm{l}$ of the reverse transcription reaction with reagents provided by Hybaid UK including $10 \%$ dimethyl sulphoxide. PCR samples were heated at $94^{\circ} \mathrm{C}$ for $2 \mathrm{~min}$, followed by 30 cycles of $94^{\circ} \mathrm{C}$ for $30 \mathrm{~s}, 55^{\circ} \mathrm{C}$ for $30 \mathrm{~s}$ and $72{ }^{\circ} \mathrm{C}$ for $30 \mathrm{~s}$, and an extension time of $5 \mathrm{~min}$ at $72^{\circ} \mathrm{C}$. The following primers were used in PCR reactions $(20$ pmol per reaction): human IL-1 (type 1) receptor (forward: ATC TAC AGA ACA AGC CTC CAG G and reverse: CCA CAC TGT AAT AGT CTT CC), human $11 \beta \mathrm{HSD}-1$ (forward: TGT AGG TTC TCT CTG TGT GTC C and reverse: GCA AAT GTT AGA GGA ACT CC), human $11 \beta$ HSD-2 (forward: GTA TTG GAG TTG AAC AGC CCC G and reverse: AGA GAC ACT TGG GAT TTA GCC C) and human COX-2 (forward: CGA GGT GTA TGT ATG AGT GTG G and reverse: GCA ATC ATC AGG CAC AGG), human GR $\alpha$ sense (forward: ACA CAG GCT TCA GGT ATC TT and reverse: ACT GCT TCT GTT GCC AAG). PCR fragments were visualised by ethidium bromide staining on $1 \%$ agarose gels.

\section{RESULTS}

\section{mRNA analysis of cancer cell lines and HOSE cells}

In order to compare levels of gene expression between HOSE cells and cancer cell lines, RNA was isolated and analysed by RT - PCR either by agarose gel electrophoresis (Figure 1) or real-time PCR (Figure 2). For HOSE cells, levels of $11 \beta \mathrm{HSD}-1, \mathrm{COX}-2$, IL-1 receptor (IL-1R) and glucocorticod receptor $\alpha(\mathrm{GR} \alpha)$ mRNA were easily detected; however, $11 \beta \mathrm{HSD}-2$ mRNA was barely detected. In contrast, all four cancer cell lines showed significantly lower levels of $11 \beta \mathrm{HSD}-1 \mathrm{mRNA}$ but higher levels of $11 \beta \mathrm{HSD}-2$, relative to HOSE cells. Whereas PEO-14 cells exhibited patterns of COX-2 and IL-1R mRNA expression similar to that of HOSE cells, these two genes were expressed at much lower levels in SKOV-3, BG-1 and PEO- 4 cells. With the exception of BG-1 cells, GR $\alpha$ mRNA was readily detected in all cells.

\section{Effect of IL-1 $\alpha$ on $11 \beta \mathrm{HSD}-1 \mathrm{mRNA}$ in cancer cell lines and HOSE cells}

Treatment of HOSE cells with IL- $1 \alpha$ dramatically enhanced the level of $11 \beta$ HSD-1 mRNA up to 28 -fold $(P<0.01)$ in a dosedependant fashion (Figure 3$)$. In contrast, with the exception of PEO-14 cells, IL- $1 \alpha$ did not alter the level of $11 \beta$ HSD- 1 mRNA in the other cell lines tested. For PEO-14 cells, a maximal three-fold induction of $11 \beta \mathrm{HSD}-1$ mRNA was observed in response to $1 \mathrm{ng} \mathrm{ml}^{-1}$ IL- $1 \alpha(P<0.01)$.

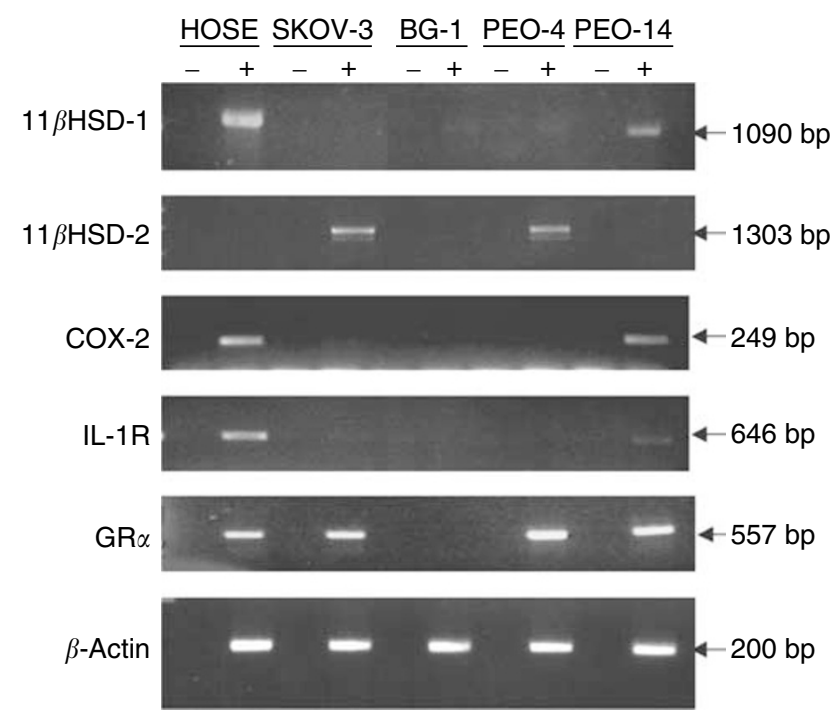

Figure I RT-PCR of I | $\beta$ HSD-I and -2, COX-2, IL-I receptor, GR $\alpha$ and $\beta$-actin using RNA isolated from HOSE, SKOV-3, BG-I, PEO-4 and PEO- 14 cells. Reactions were performed in the absence $(-)$ and presence $(+)$ of reverse transcriptase. One example of three separate experiments is presented.

\section{Effect of IL- $1 \alpha$ on $11 \beta$ HSD- 2 mRNA in cancer cell lines and HOSE cells}

The level of $11 \beta$ HSD-2 mRNA in HOSE cells was unaffected by the presence of IL- $1 \alpha$ except for marginal stimulation in response to $1 \mathrm{ng} \mathrm{ml}^{-1}$ IL- $1 \alpha$ (1.6-fold; $\left.P<0.001\right)$, see Figure 4 . The greatest stimulation of $11 \beta \mathrm{HSD}-2$ mRNA level was observed in PEO- 4 cells treated with $0.5 \mathrm{ng} \mathrm{ml}^{-1}$ IL- $1 \alpha(4.6$-fold; $P<0.05)$. For BG-1 and PEO-14 cells, $11 \beta$ HSD-2 mRNA level was similarly observed to increase in response to IL- $1 \alpha$; however, this was not significant. In contrast, addition of IL- $1 \alpha$ to SKOV-3 cells induced a significant decrease of $11 \beta \mathrm{HSD}-2$ mRNA level (two-fold; $P<0.01$ ).

\section{Effect of IL- $1 \alpha$ on COX-2 mRNA in cancer cell lines and HOSE cells}

Treatment of HOSE cells with IL- $1 \alpha$ dramatically increased the level of COX-2 mRNA in a dose-dependant fashion exhibiting maximal stimulation with $1 \mathrm{ng} \mathrm{ml}^{-1}$ IL- $1 \alpha$ (28-fold; $\left.P<0.001\right)$, see Figure 5. In contrast, the level of COX-2 mRNA in the cell lines was largely unaffected; only a mild stimulation was observed in response to $1 \mathrm{ng} \mathrm{ml}^{-1} \mathrm{IL}-1 \alpha$ in either SKOV-3 or PEO-14 cells (2.8-fold, $P<0.05)$

\section{DISCUSSION}

This study reveals unique immuno-endocrine signatures for four ovarian adenocarcinoma cell lines (SKOV-3, BG-1, PEO-4 and PEO-14) that clearly distinguish them from the nontransformed HOSE cell type from which most ovarian cancers are presumed to derive. Whereas primary HOSE cell cultures show highly IL- $1 \alpha$ responsive COX-2 and $11 \beta \mathrm{HSD}-1$ gene expression, neither gene in the cancer cell lines responded markedly to IL- $1 \alpha$. In contrast, whereas HOSE cells exhibited a low level of $11 \beta$ HSD-2 mRNA that was mildly responsive to IL- $1 \alpha(1.6$-fold, $P<0.001)$, all cell lines exhibited a higher basal level $(P<0.01)$ of $11 \beta$ HSD- 2 mRNA that was in some cases further stimulated in PEO-4 cells (five-fold; $P<0.05$ ) or suppressed in SKOV-3 cells (two-fold; $P<0.01$ ), in response to IL- $1 \alpha$. Increased expression of COX-2 is a hallmark of the inflammatory response. The stimulation of COX-2 in HOSE cells $(28$-fold, $P<0.001)$ and relative lack of stimulation in 

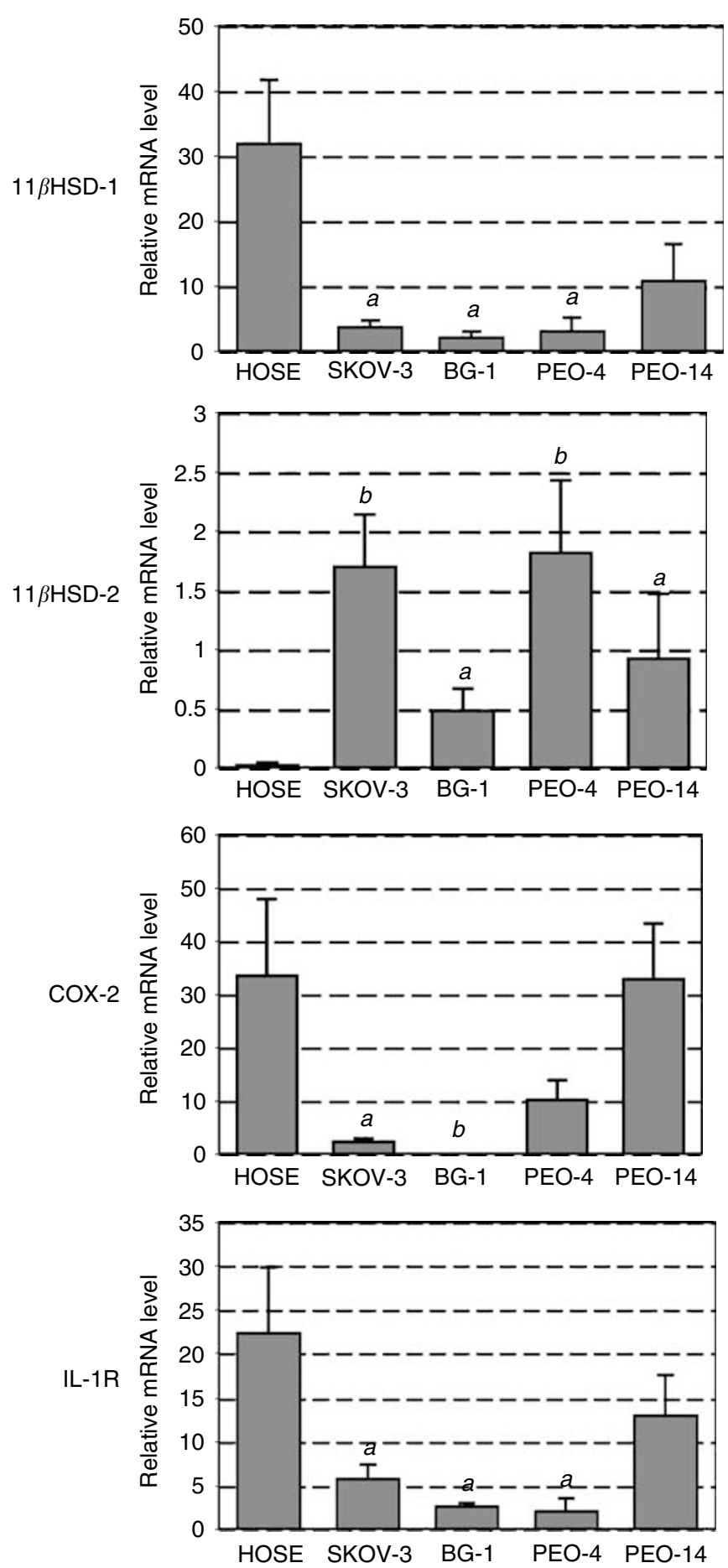

Figure 2 Real-time PCR using RNA isolated from HOSE, SKOV-3, BG- I, PEO-4 and PEO-I 4 cells. Level of mRNA was standardised to I $8 \mathrm{~S}$ using an internal control and each sample normalised to a reference sample. Data $(n=4)$ are presented as fold increase and mean \pm s.e.m. Letters denote significance relative to HOSE cells: $a: P<0.01$ and $b$ : $P<0.00$ I.

SKOV-3, BG-1 and PEO- 4 cancer cell lines, in response to IL- $\alpha$, therefore, suggests that these cancer cell lines have lost the ability to induce a normal inflammatory response. It remains to be determined if these findings translate to primary ovarian cancer cells; however, we consider the data presented here to justify such an analysis if the ethical and logistical constraints in establishing suitable primary cell cultures from sufficient patients can be overcome.

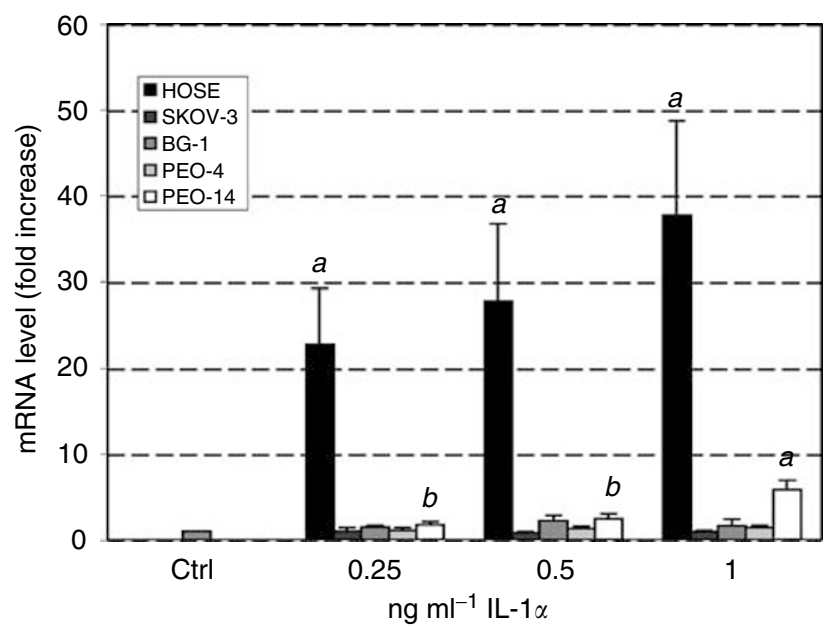

Figure 3 Real-time PCR of I I $\beta \mathrm{HSD}$ - I in HOSE, SKOV-3, BG- I, PEO-4 and PEO- $\mid 4$ cells treated with increasing concentrations of $|\mathrm{L}-| \alpha$. Level of mRNA was standardised to I8S using an internal control and normalised to untreated cells. Data $(n=6)$ are presented as mean \pm s.e.m. Letters denote significance above control: $a: P<0.05$ and $b: P<0.01$.

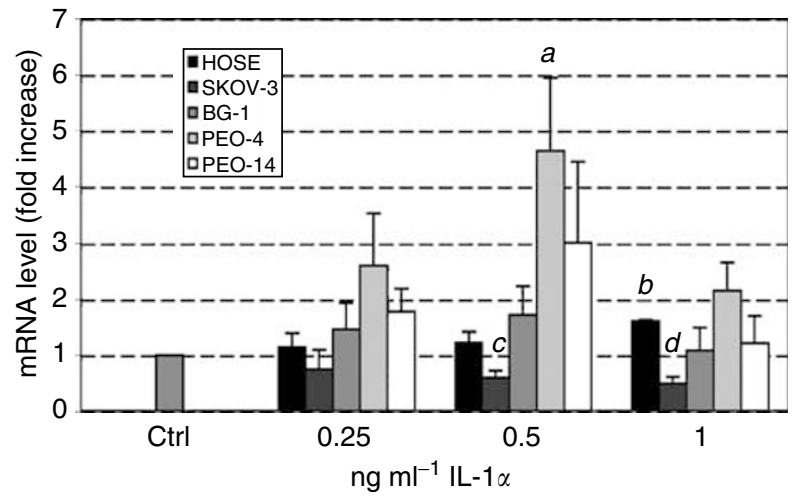

Figure 4 Real-time PCR of I I $\beta$ HSD-2 in HOSE, SKOV-3, BG-I, PEO-4 and PEO- $\mid 4$ cells treated with increasing concentrations of IL- $\mid \alpha$. Level of mRNA was standardised to $18 \mathrm{~S}$ using an internal control and normalised to untreated cells. Data $(n=6)$ are presented as mean \pm s.e.m. Letters denote significance above control: $a$ : $P<0.05$ and $b: P<0.001$, and below control: c: $P<0.05$ and $d: P<0.01$.

Based on the divergent effects of $11 \beta \mathrm{HSD}-1$ and -2 on cell proliferation observed in vitro, Rabbitt et al (2003) have previously suggested that the ability of $11 \beta \mathrm{HSD}-1$ to generate cortisol might act as an autocrine antiproliferative, prodifferentiation stimulus in normal adult tissues. In contrast, the cortisol-inactivating properties of $11 \beta \mathrm{HSD}-2$ might lead to pro-proliferative effects, particularly in tumours. Our finding that normal OSE cells, unlike cell lines derived from ovarian tumours, abundantly express $11 \beta \mathrm{HSD}-1$ mRNA but are essentially devoid of $11 \beta \mathrm{HSD}-2$ mRNA, supports the concept that the pattern of $11 \beta \mathrm{HSD}$ isoform expression is a defining feature of neoplastic cellular transformation that could have particular relevance to the ovary.

Based on the level of IL-1R mRNA, the differential effects observed in response to IL- $1 \alpha$ between cell lines and HOSE cells may simply result from differential IL-1R expression. Although IL-1R mRNA is more abundant in HOSE cells and PEO-14 cells, IL-1R mRNA is nevertheless detectable in the other cell lines tested (Figure 2). The observation that the level of $11 \beta \mathrm{HSD}-2 \mathrm{mRNA}$ is more greatly increased in response to IL- $1 \alpha$ in cancer cell lines relative to HOSE cells (Figure 4) may suggest that expression of IL- $1 \mathrm{R}$ is not limiting the effects of IL- $1 \alpha$ on gene expression in the 


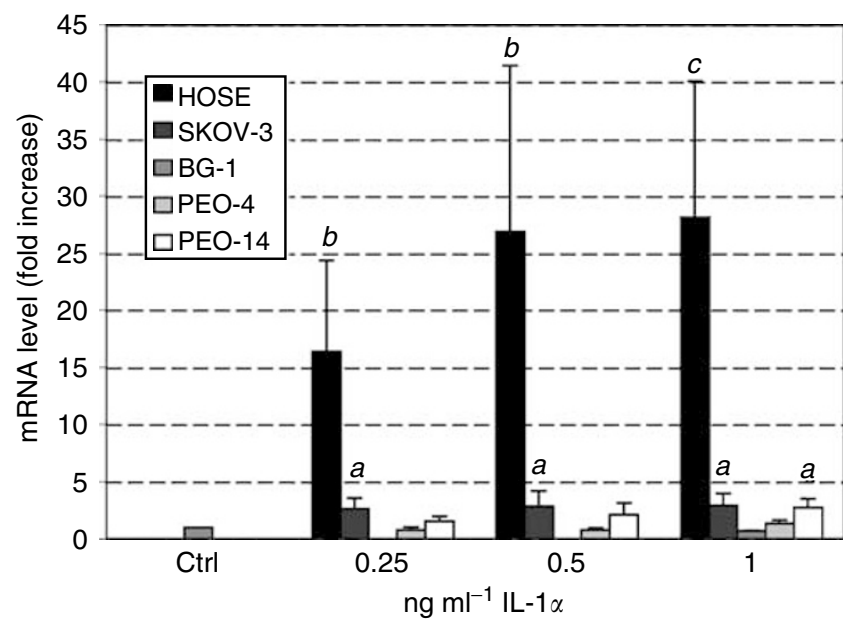

Figure 5 Real-time PCR of COX-2 in HOSE, SKOV-3, BG- I, PEO-4 and PEO-I 4 cells treated with increasing concentrations of IL- $\mid \alpha$. Level of mRNA was standardised to I $8 \mathrm{~S}$ using an internal control and normalised to untreated cells. Data $(n=6)$ are presented as mean \pm s.e.m. Letters denote significance above control: $a: P<0.05, b: P<0.01$ and $c: P<0.001$.

cancer cell lines. In the case of SKOV-3, IL-1R signalling was previously shown to be functional by demonstrating activation of NF-kappa in response to IL-1 $\beta$ (Bonizzi et al, 1996).

IL-1R signalling is initiated by receptor-associated proteins that include TRAFs (TNF receptor-associated factors; Inoue et al, 2000), TIRs (Toll IL-1 receptor proteins; McGettrick and O'Neill, 2004) and IRAKs (IL-1 receptor-associated kinases; Janssens and Beyaert, 2003). IL-1 also activates MAP kinase pathways: p38 (Guan et al, 1997), ERK 1/2 ((Laporte et al, 1999) and JNK (Guan et al, 1998) and subsequently activates transcription factors such as NF-k $\beta$ (Roshak et al, 1996). In addition, modulation of IL-1R signalling is altered by other signalling proteins such as Smads, SOCSs (suppressor of cytokine signalling; Yoshimura et al, 2003) and STATs (Morton et al, 1999). In one study of ovarian carcinoma, SOCS 1 and 2 genes were demonstrated to be silenced due to hypermethylation (Sutherland et al, 2004) and a number of studies have identified increased levels of STAT proteins (particularly STAT 3) in ovarian cancers (Huang et al, 2000; Chen et al, 2004; Meinhold-Heerlein et al, 2005; Silver et al, 2004). We are currently focusing our attention on IL-1R signalling in order to identify any differences between primary HOSE cells and ovarian cancer cells.

Although there are clearly differences between all cell lines and HOSE cells, the PEO-14 cell line appears most closely to resemble HOSE cells. Relative to SKOV-3, BG-1 and PEO-4 cells, PEO-14 and HOSE cells express higher levels of $11 \beta$ HSD-1, COX-2 and IL-1R mRNA and lower levels of $11 \beta$ HSD- 2 mRNA. Moreover, whereas $11 \beta$ HSD- 2 mRNA is unaltered in response to IL- $1 \alpha$, the level of $11 \beta$ HSD -1 and COX-2 mRNA is stimulated in response to IL- $1 \alpha$ in both HOSE and PEO-14 cells. The observation that the PEO-14 cell line most closely resembles HOSE cells is consistent with the origin of PEO-14 cells from a well-differentiated serous adenocarcinoma; SKOV-3, BG-1 and PEO-4 cells originate from poorly differentiated serous adenocarcinoma. Since the cell lines used in this study are derived from different ovarian cancers at different stages of differentiation, it is possible that the heterogeneity observed is reflective of these differences. Indeed, the responses observed may provide a novel means of defining such differences at a functional level.

Whereas $11 \beta \mathrm{HSD}-1$ predominantly catalyses 11 -oxoreduction of cortisone to cortisol, $11 \beta \mathrm{HSD}-2$ converts cortisol to cortisone. The pattern of $11 \beta$ HSD type 1 and 2 expression described in HOSE cells is therefore consistent with an increased conversion of cortisone to cortisol upon exposure to IL- $1 \alpha$, previously identified in HOSE cells (Yong et al, 2002). Thus, upregulation of $11 \beta$ HSD-1 without a measurable change in $11 \beta \mathrm{HSD}-2$ would be predicted to result in increased conversion of systemically derived cortisone to anti-inflammatory cortisol in the OSE. This is proposed as a compensatory anti-inflammatory mechanism that accompanies the inflammatory response (e.g. COX-2 expression) to cytokines shown by the OSE during LH-induced ovulation in vivo.

Receptors for glucocorticoids are present in tumour cells of almost $90 \%$ of ovarian cancers, and these hormones inhibit ovarian cancer cell growth (Karlan et al, 1994). It is therefore of interest that three epithelial cancer cell lines (SKOV-3, BG-1 and PEO-4) exhibit a low basal level of $11 \beta \mathrm{HSD}-1$ that is unresponsive to inflammatory stimulation, yet have gained a basal level of $11 \beta \mathrm{HSD}-2$ mRNA that, in the case of the PEO- 4 cell line, is cytokine responsive. For HOSE cells, addition of cortisol augments IL- $1 \alpha$ stimulation of $11 \beta$ HSD-1, but decreases IL- $1 \alpha$ induced COX-2 expression (Rae et al, 2004). The increased level of cortisol, in response to IL- $1 \alpha$ induced $11 \beta \mathrm{HSD}-1$, is thereby envisaged to function in an anti-inflammatory manner. The impact of glucocorticoids on IL- $1 \alpha$ responsiveness in ovarian cell lines remains to be assessed; however, it is interesting to note that unlike HOSE and other cell lines, the BG-1 cell line does not appear to express GR $\alpha$.

The potential pathophysiological relevance of these findings relates to the likelihood that serial inflammatory injury associated with ovulation predisposes the OSE to neoplastic transformation. Factors related to inflammation of the OSE have been associated with increased risk of ovarian cancer (Ness and Cottreau, 1999; Ness et al, 2000) and exposure to anti-inflammatory agents has been shown to inhibit tumour invasion and protease production by ovarian carcinoma cells (Akhmedkhanov et al, 2001). It is therefore of obvious interest that all cell lines studied here appear to have largely lost their capacity to mount an inflammatory response to IL- $1 \alpha$ in terms of increased $11 \beta$ HSD- 1 expression and hence increased formation of anti-inflammatory, proapoptotic glucocorticoids. It remains to be determined whether this loss of response to proinflammatory cytokines is a feature of the primary tumours from which ovarian cancer cell lines are derived and whether it might be causal or consequential to disease progress.

\section{ACKNOWLEDGEMENTS}

We thank Catherine Murray, Hilary Critchley and the surgical staff at the Simpson maternity wards for collection of HOSE cells. This research was supported by The Medical Research Council Programme Grant number 0000066 and The European Commission EU Contract EUK1-CT-2002-00128 (EURISKED).

\section{REFERENCES}

Akhmedkhanov A, Toniolo P, Zeleniuch-Jacquotte A, Kato I, Koenig KL, Shore RE (2001) Aspirin and epithelial ovarian cancer. Prev Med 33: $682-687$

Andersen CY, Hornnes P (1994) Intrafollicular concentrations of free cortisol close to follicular rupture. Hum Reprod 9: 1944-1949
Auersperg N, Wong AS, Choi KC, Kang SK, Leung PC (2001) Ovarian surface epithelium: biology, endocrinology, and pathology. Endocr Rev 22: $255-288$

Benchekroun MN, Parker R, Dabholkar M, Reed E, Sinha BK (1995) Effects of interleukin-1 alpha on DNA repair in human ovarian carcinoma 
(NIH:OVCAR-3) cells: implications in the mechanism of sensitization of cis-diamminedichloroplatinum (II). Mol Pharmacol 47: 1255-1260

Bonizzi G, Dejardin E, Piret B, Piette J, Merville MP, Bours V (1996) Interleukin-1 beta induces nuclear factor kappa B in epithelial cells independently of the production of reactive oxygen intermediates. Eur J Biochem 242: $544-549$

Buescher ES, McIlheran SM, Banks SM, Kudelka AP, Kavanagh JJ, VadhanRaj S (1993) The effects of interleukin-1 therapy on peripheral blood granulocyte function in humans. Cancer Immunol Immunother 37: $26-$ 30

Bukulmez O, Arici A (2000) Leukocytes in ovarian function. Hum Reprod Update 6: $1-15$

Burger RA, Grosen EA, Ioli GR, Van Eden ME, Brightbill HD, Gatanaga M, DiSaia PJ, Granger GA, Gatanaga T (1994) Host-tumor interaction in ovarian cancer. Spontaneous release of tumor necrosis factor and interleukin-1 inhibitors by purified cell populations from human ovarian carcinoma in vitro. Gynecol Oncol 55: 294-303

Chen H, Ye D, Xie X, Chen B, Lu W (2004) VEGF, VEGFRs expressions and activated STATs in ovarian epithelial carcinoma. Gynecol Oncol 94(3): $630-635$

Colgin DC, Murdoch WJ (1997) Evidence for a role of the ovarian surface epithelium in the ovulatory mechanism of the sheep: secretion of urokinase-type plasminogen activator. Anim Reprod Sci 47: 197-204

Czernobilsky B (1985) Co-expression of cytokeratin and vimentin filaments in mesothelial, granulosa and rete ovarii cells of the human ovary. Eur Cell Biol 37: $175-190$

Escher G, Galli I, Vishwanath BS, Frey BM, Frey FJ (1997) Tumor necrosis factor alpha and interleukin lbeta enhance the cortisone/cortisol shuttle. J Exp Med 186: $189-198$

Espey LL (1980a) Ovulation as an inflammatory reaction-a hypothesis. Biol Reprod 22: $73-106$

Espey LL (1980b) Current status of the hypothesis that mammalian ovulation is comparable to an inflammatory reaction. Biol Reprod 50: $233-238$

Fathalla MF (1971) Incessant ovulation - a factor in ovarian neoplasia? Lancet 17: 163

Fujiwaki R, Hata T, Miyazaki K, Kawamura T, Inada K (1997) Elevation of serum interleukin-1 receptor antagonist levels in women with gynaecological cancers. Br J Obstet Gynaecol 104: 1407-1408

Guan Z, Baier LD, Morrison AR (1997) p38 mitogen-activated protein kinase down-regulates nitric oxide and up-regulates prostaglandin E2 biosynthesis stimulated by interleukin-1beta. J Biol Chem 272(12): 8083 8089

Guan Z, Buckman SY, Miller BW, Springer LD, Morrison AR (1998) Interleukin-1beta-induced cyclooxygenase-2 expression requires activation of both c-Jun NH2-terminal kinase and p38 MAPK signal pathways in rat renal mesangial cells. J Biol Chem 273(44): 28670-28676

Hefler LA, Ludwig E, Lebrecht A, Zeillinger R, Tong-Cacsire D, Koelbl H, Leodolter S, Tempfer CB (2002) Polymorphisms of the interleukin-1 gene cluster and ovarian cancer. J Soc Gynecol Invest 9: 386-390

Hillier SG, Tetsuka M (1998) An anti-inflammatory role for glucocorticoids in the ovaries? J Reprod Immunol 39: $21-27$

Huang M, Page C, Reynolds RK, Lin J (2000) Constitutive activation of stat 3 oncogene product in human ovarian carcinoma cells. Gynecol Oncol 79(1): $67-73$

Huleihel M, Maymon E, Piura B, Prinsloo I, Benharroch D, Yanai-Inbar I, Glezerman M (1997) Distinct patterns of expression of interleukin-1 alpha and beta by normal and cancerous human ovarian tissues. Eur Cytokine Networks 8: 179-187

Inoue J, Ishida $\mathrm{T}$, Tsukamoto $\mathrm{N}$, Kobayashi $\mathrm{N}$, Naito A, Azuma $\mathrm{S}$, Yamamoto $\mathrm{T}$ (2000) Tumor necrosis factor receptor-associated facto (TRAF) family: adapter proteins that mediate cytokine signaling. Exp Cell Res 254(1): 14-24

Janssens S, Beyaert R (2003) Functional diversity and regulation of different interleukin-1 receptor-associated kinase (IRAK) family members. Mol Cell 11(2): $293-302$

Karlan BY, Jones J, Slamon DJ, Lagasse LD (1994) Glucocorticoids stabilize HER-2/neu messenger RNA in human epithelial ovarian carcinoma cells. Gynecol Oncol 53: $70-77$

Kawakami Y, Nagai N, Ota S, Ohama K, Yamashita U (1997) Interleukin-1 as an autocrine stimulator in the growth of human ovarian cancer cells. Hiroshima J Med Sci 46: 51-59

Kondera-Anasz Z, Mielczarek-Palacz A, Switala J (2003) Significantly increased interleukin-1A and interleukin-1 soluble type II receptor levels in women with ovarian cancer. Ginekol Pol 74: 761 -766
Kutteh WH, Kutteh CC (1992) Quantitation of tumor necrosis factor-alpha, interleukin-1 beta, and interleukin- 6 in the effusions of ovarian epithelia neoplasms. Am J Obstet Gynecol 167: $1864-1869$

Langdon SP, Lawrie SS, Hay FG, Hawkes MM, McDonald A, Hayward IP, Schol DJ, Hilgers J, Leonard RC, Smyth JF (1988) Characterization and properties of nine human ovarian adenocarcinoma cell lines. Cancer Res 48: $6166-6172$

Laporte JD, Moore PE, Abraham JH, Maksym GN, Fabry B, Panettieri Jr RA Shore SA (1999) Role of ERK MAP kinases in responses of cultured human airway smooth muscle cells to IL-1beta. Am J Physiol 277: L943 L951

Lee AM, Vadhan-Raj S, Hamilton Jr RF, Scheule RK, Holian A (1993) The in vivo effects of rhIL-1 alpha therapy on human monocyte activity. J Leukoc Biol 54: 314-321

Marth C, Zeimet AG, Herold M, Brumm C, Windbichler G, Muller-Holzner E, Offner F, Feichtinger H, Zwierzina H, Daxenbichler G (1996) Different effects of interferons, interleukin-1beta and tumor necrosis factor-alpha in normal (OSE) and malignant human ovarian epithelial cells. Int $J$ Cancer 67: $826-830$

McGettrick AF, O’Neill LA (2004) The expanding family of MyD88-like adaptors in Toll-like receptor signal transduction. Mol Immunol 41(6-7): $577-582$

Meinhold-Heerlein I, Bauerschlag D, Hilpert F, Dimitrov P, Sapinoso LM, Orlowska-Volk M, Bauknecht T, Park TW, Jonat W, Jacobsen A, Sehouli J, Luttges J, Krajewski M, Krajewski S, Reed JC, Arnold N, Hampton GM (2005) Molecular and prognostic distinction between serous ovarian carcinomas of varying grade and malignant potential. Oncogene 24(6): $1053-1065$

Michael AE, Thurston LM, Rae MT (2003) Glucocorticoid metabolism and reproduction: a tale of two enzymes. Reproduction 126: 425-441

Morton NM, de Groot RP, Cawthorne MA, Emilsson V (1999) Interleukin1beta activates a short STAT-3 isoform in clonal insulin-secreting cells. FEBS Lett 442(1): $57-60$

Murdoch WJ, Wilken C, Young DA (1999) Sequence of apoptosis and inflammatory necrosis within the formative ovulatory site of sheep follicles. J Reprod Fertil 117: 325-329

Ness RB, Cottreau C (1999) Possible role of ovarian epithelial inflammation in ovarian cancer. J Natl Cancer Inst 91: 1459-1467

Ness RB, Grisso JA, Cottreau C, Klapper J, Vergona R, Wheeler JE, Morgan M, Schlesselman JJ (2000) Factors related to inflammation of the ovarian epithelium and risk of ovarian cancer. Epidemiology 11: $111-117$

Niven D, Rae MT, Critchley HOD, Hillier SG (2004) An anti-inflammatory role for progesterone at the human ovarian surface. Br Endocrine Soc Conf 2004: OC4

Ozols RF (1991) Ovarian cancer: new clinical approaches. Cancer Treat Rev 18(Suppl A): $77-83$

Punnonen J, Heinonen PK, Kuoppala T, Jansen CT, Punnonen R (1991) Production of interleukin-1 beta and tumour necrosis factor-alpha in patients with benign or malignant ovarian tumours. J Cancer Res Clin Oncol 117: 587 - 592

Rabbitt EH, Gittoes NJ, Stewart PM, Hewison M (2003) 11beta-hydroxysteroid dehydrogenases, cell proliferation and malignancy. J Steroid Biochem Mol Biol 85: 415-421

Rae MT, Niven D, Critchley HOD, Harlow CR, Hillier SG (2004) Antiinflammatory steroid action in human ovarian surface epithelial cells. J Clin Endocr Metab 89(9): 4538-4544

Roshak AK, Jackson JR, McGough K, Chabot-Fletcher M, Mochan E, Marshall LA (1996) Manipulation of distinct NFkappaB proteins alters interleukin-1beta-induced human rheumatoid synovial fibroblast prostaglandin E2 formation. J Biol Chem 271(49): 31496-31501

Salazar H, Godwin AK, Daly MB, Laub PB, Hogan WM, Rosenblum N, Boente MP, Lynch HT, Hamilton TC (1996) Microscopic benign and invasive malignant neoplasms and a cancer-prone phenotype in prophylactic oophorectomies. J Natl Cancer Inst 18: 1810-1820

Sehouli J, Mustea A, Koensgen D, Chen FC, Lichtenegger W (2003a) Interleukin-1 receptor antagonist gene polymorphism is associated with increased risk of epithelial ovarian cancer. Ann Oncol 14: $1501-1504$

Sehouli J, Mustea A, Konsgen D, Katsares I, Lichtenegger W (2002) Polymorphism of IL-1 receptor antagonist gene: role in cancer. Anticancer Res 22(6A): $3421-3424$

Sehouli J, Mustea A, Koensgen D, Lichtenegger W (2003b) Interleukin-1 receptor antagonist gene polymorphism in epithelial ovarian cancer. Cancer Epidemiol Biomarkers Prev 12: 1205-1208

Silver DL, Naora H, Liu J, Cheng W, Montell DJ (2004) Activated signal transducer and activator of transcription (STAT) 3: localization in focal 
adhesions and function in ovarian cancer cell motility. Cancer Res 64(10): $3550-3558$

Stewart PM, Mason JI (1995) Cortisol to cortisone: glucocorticoid to mineralocorticoid. Steroids 60: $143-146$

Sutherland KD, Lindeman GJ, Choong DY, Wittlin S, Brentzell L, Phillips W, Campbell IG, Visvader JE (2004) Differential hypermethylation of SOCS genes in ovarian and breast carcinomas. Oncogene 23(46): 77267733

Tannin GM, Agarwal AK, Monder C, New MI, White PC (1991) The human gene for 11 beta-hydroxysteroid dehydrogenase. Structure, tissue distribution, and chromosomal localization. J Biol Chem 266: 16653-16658

Vadhan-Raj S, Kudelka AP, Garrison L, Gano J, Edwards CL, Freedman RS, Kavanagh JJ (1994) Effects of interleukin-1 alpha on carboplatin-induced thrombocytopenia in patients with recurrent ovarian cancer. J Clin Oncol 12: $707-714$

van Niekerk CC, Boerman OC, Ramaekers FCS, Poels LG (1991) Marker profile of different phases in the transition of normal human ovarian epithelium to ovarian carcinomas. Am J Pathol 138: 455-463
Verschraegen CF, Kudelka AP, Termrungruanglert W, de Leon CG, Edwards CL, Freedman RS, Kavanagh JJ, Vadhan-Raj S (1996) Effects of interleukin-1 alpha on ovarian carcinoma in patients with recurrent disease. Eur J Cancer 9: 1609-1611

Wang Z, Lee KB, Reed E, Sinha BK (1996) Sensitization by interleukinlalpha of carboplatinum anti-tumor activity against human ovarian (NIH:OVCAR-3) carcinoma cells in vitro and in vivo. Int J Cancer 68: $583-587$

Yong PY, Harlow C, Thong KJ, Hillier SG (2002) Regulation of 11betahydroxysteroid dehydrogenase type 1 gene expression in human ovarian surface epithelial cells by interleukin-1. Hum Reprod 17: 2300-2306. Erratum in: Hum Reprod (2002) 17:3009

Yoshimura A, Mori H, Ohishi M, Aki D, Hanada T (2003) Negative regulation of cytokine signaling influences inflammation. Curr Opin Immunol 15(6): 704-708

Zeisler H, Tempfer C, Joura EA, Sliutz G, Koelbl H, Wagner O, Kainz C (1998) Serum interleukin 1 in ovarian cancer patients. Eur J Cancer 34: $931-933$ 